\title{
Pregnancy and Bovine Somatotropin in Nonlactating Dairy Cows: II. Endometrial Gene Expression Related to Maintenance of Pregnancy
}

\author{
A. Guzeloglu, ${ }^{1}$ T. R. Bilby, ${ }^{1}$ A. Meikle, ${ }^{2}$ S. Kamimura, ${ }^{3}$ A. Kowalski, ${ }^{4}$ \\ F. Michel, ${ }^{1}$ L. A. MacLaren, ${ }^{5}$ and W. W. Thatcher ${ }^{1}$ \\ ${ }^{1}$ Department of Animal Sciences, \\ University of Florida, Gainesville 32611-0910 \\ ${ }^{2}$ Department of Biochemistry, Faculty of Veterinary Medicine, \\ University of Uruguay, Montevideo, Uruguay \\ ${ }^{3}$ Department of Veterinary Medicine, Faculty of Agriculture, \\ Kagoshima University, Kagoshima, Japan \\ ${ }^{4}$ College of Agriculture, Dept. Animal Production, \\ Universidad Centroccidental Lisandro Alvarado, \\ Barquisimeto, Lara, Venezuela \\ ${ }^{5}$ Department of Plant and Animal Sciences, \\ Nova Scotia Agricultural College, Truro, Canada
}

\section{ABSTRACT}

The objective was to evaluate the effects of pregnancy and bovine somatotropin (bST) on endometrial gene and protein expression related to maintenance of pregnancy in nonlactating dairy cows at $d 17$. In endometrial tissues, treatment with bST increased the steady state concentration of oxytocin receptor (OTR) mRNA; bSTtreated cyclic (bST-C) cows had greater OTR mRNA than bST-treated pregnant (bST-P) cows. Estradiol receptor $\alpha(\mathrm{ER} \alpha)$ mRNA was reduced in bST-P cows compared with control P and C (no bST) cows. Western blotting revealed that pregnancy decreased the abundance of ER $\alpha$ protein, and bST stimulated an increase in $\mathrm{ER} \alpha$ protein in $\mathrm{C}$ and $\mathrm{P}$ cows. Treatment with bST increased steady state concentrations of progesterone receptor (PR) mRNA. No differences were detected in steady state mRNA concentrations of prostaglandin $\mathrm{H}$ synthase-2 (PGHS-2), prostaglandin E synthase, and prostaglandin $\mathrm{F}$ synthase due to pregnancy or bST treatment. However, PGHS-2 protein was increased in response to pregnancy and bST treatment. Immunostaining indicated that $\mathrm{P}$ decreased $\mathrm{ER} \alpha$ protein in luminal epithelium and increased PR protein in epithelial cells of the uterine glands. The PR protein response in the glands was less in bST-P cows than in P cows. In the stromal layer of the endometrium, bST decreased $\mathrm{PR}$ protein abundance in $\mathrm{C}$ and $\mathrm{P}$ cows. The PGHS-2 protein was localized exclusively in the luminal epithelium cells of endometrium and was increased in P cows.

Received April 4, 2004.

Accepted June 2, 2004.

Corresponding author: William W. Thatcher; e-mail: thatcher@ animal.ufl.edu.
In conclusion, distinctly different mRNA and protein responses were detected between $\mathrm{C}$ and $\mathrm{P}$ cows related to prostaglandin biosynthesis, and bST-induced changes may potentially impact mechanisms associated with maintenance of pregnancy in nonlactating cows.

(Key words: pregnancy, bovine somatotropin, endometrium)

Abbreviation key: $\mathbf{C}=$ cyclic, $\mathbf{C L}=$ corpus luteum, $\mathbf{E R} \boldsymbol{\alpha}=$ estradiol receptor $\alpha$, IFN- $\boldsymbol{\tau}=$ interferon $-\tau$, OTR = oxytocin receptor, $\mathbf{P}=$ pregnant, $\mathbf{P G}=$ prostaglandin, PGES = prostaglandin E synthase, PGFM = 13, 14-dihydro 15-keto $\mathrm{PGF}_{2 \alpha}$, PGFS = prostaglandin $\mathrm{F}$ synthase, PGHS-2 = prostaglandin $\mathrm{H}$ synthase-2, $\mathbf{P R}=$ progesterone receptor .

\section{INTRODUCTION}

Excessive embryonic mortality of nearly $40 \%$ in cattle is due partly to physiological alterations resulting in discord between the maternal environment and the conceptus, which results in failure to maintain the corpus luteum $(\mathbf{C L})$ and secretion of progesterone (Thatcher et al., 1995). In ruminants, regression of the CL is due to a positive feedback loop between endometrial prostaglandin $\left(\mathrm{PGF}_{2 \alpha}\right)$ and luteal oxytocin secretion (Flint et al., 1992). The common factor associated with initiation of luteolysis in cattle and sheep appears to be an increase in endometrial sensitivity to oxytocin due to the presence of the oxytocin receptor (OTR) (McCracken et al., 1999).

Establishment and maintenance of pregnancy requires integration of endocrine and paracrine signals. Embryonic interferon- $\tau(\mathbf{I F N}-\boldsymbol{\tau})$ inhibits endometrial 
$\mathrm{PGF}_{2 \alpha}$ secretion by several possible mechanisms (Mann et al., 1999). Interferon- $\tau$ inhibits expression of the OTR in the luminal epithelium in both sheep and cattle (Farin et al., 1990; Wathes and Lamming, 1995), and induces a prostaglandin (PG) synthesis inhibitor (Thatcher et al., 1995). Spencer and Bazer (1995) suggested that IFN- $\tau$ inhibits OTR upregulation by inhibiting a preceding increase in estradiol receptor $\alpha(\mathbf{E R} \boldsymbol{\alpha})$ expression in sheep. In cattle, different responses have been reported for ER $\alpha$ in early pregnancy such as no changes (Robinson et al., 1999), or a decrease in expression within all layers of the endometrium at $d 16$ and 18 of pregnancy (Robinson et al., 2001).

Although progesterone is the principal hormone implicated in the control of embryo development and IFN$\tau$ secretion (Mann and Lamming, 2001), the role of the progesterone receptor $(\mathbf{P R})$ in pregnancy has been obscure. Studies consistently report a loss of PR in the uterine epithelium near the time of luteolysis in both sheep and cattle (Spencer and Bazer, 1995; Wathes and Lamming, 1995; Robinson et al., 2001). This is probably due to a downregulation of $\mathrm{PR}$ from long exposure to progesterone during the late luteal phase. The resulting loss of progesterone dominance on the uterus has been suggested to activate OTR expression and subsequent luteolysis (Wathes and Lamming, 1995). However, an effect of pregnancy on epithelial PR expression before luteolysis could not be detected in ewes (Spencer and Bazer, 1995) or cows (Robinson et al., 1999), probably because PR expression was very low.

During the period of CL maintenance in early pregnancy, prostaglandin $\mathrm{H}$ synthase-2 (PGHS-2) is regulated in ruminant endometrium. Around d 17, expression of PGHS-2 protein was sustained in the pregnant endometrium and terminated in the cyclic endometrium of ewes (Charpigny et al., 1997b). Kim et al. (2003) reported that PGHS-2 mRNA expression was greater in endometrium from pregnant ewes between d 10 and 18 of the cycle, whereas cyclic ewes had abundant concentrations on $\mathrm{d} 10$ and 14, that decreased by d 16. Prostaglandin F synthase (PGFS) and prostaglandin E synthase (PGES) are 2 enzymes downstream of PGHS-2 that catalyze the conversion of prostaglandin $\mathrm{H}_{2}$ to $\mathrm{PGF}_{2 \alpha}$ and $\mathrm{PGE}_{2}$, respectively. Successful establishment of pregnancy may regulate the balance between the luteolysin $\left(\mathrm{PGF}_{2 \alpha}\right)$ and the luteotropin and antiluteolytic factor $\left(\mathrm{PGE}_{2}\right)$. It is not known whether relative expression of the 2 synthetic enzymes changes during the bovine pregnancy recognition process.

Programs to optimize reproductive performance in dairy cattle have received considerable attention. Recently, bST treatment was shown to increase pregnancy rates when given as part of a timed AI protocol in lactating dairy cows (Moreira et al., 2000, 2001). Evidence exists for cross-talk between hormonal signal-transduction systems such as ER $\alpha$ with IGF-I (Klotz et al., 2002), and bST with IFN- $\tau$ (Badinga et al., 2002). Effects of bST on fertility may involve an interaction between bST and IFN- $\tau$ signaling pathways to regulate PG secretion or other effector responses critical for maintenance of pregnancy. Molecular and cellular mechanisms induced by bST that regulate bovine conceptus growth and endometrial gene expressions at the time of pregnancy recognition are unknown. It has been shown that growth hormone receptor 1a is present in endometrium, and that bST downregulates its receptor (Kirby et al., 1996). In those experiments, treatment with bST failed to alter endometrial expression of the IGF system (Kirby et al., 1996).

The objective of the present study was to carry out a comprehensive examination of the effects of pregnancy and bST on the regulation of the proteins in uterine endometrium that are known to influence pregnancy recognition. Relative amounts of mRNA and their respective proteins for the $\mathrm{ER} \alpha$, PR, OTR, and the prostaglandin synthetic enzymes were examined in a nonlactating dairy cow model.

\section{MATERIALS AND METHODS}

\section{Materials}

Gonadotropin-releasing hormone (Fertagyl; Intervet Inc., Milsboro, DE), $\mathrm{PGF}_{2 \alpha}$ (Lutalyse; Pfizer Animal Health, Kalamazoo, MI), and bST (Posilac; Monsanto Co., St. Louis, MO) were used for experimental treatments of cows. All other materials were purchased from the following companies: Trizol, cDNA Cycle kit, TOPO vector (TOPO TA Cloning Kits); Random Primers DNA Labeling System (Invitrogen Corp., Carlsbad, CA); Taq polymerase (cat \# M166A; Promega Corp., Madison, WI); monoclonal mouse antibodies for ER $\alpha$ (cat\# sc-787; Santa Cruz Biotechnology, Santa Cruz, CA); PR (cat\# 18 to 0172; Zymed, South San Francisco, CA); polyclonal rabbit antibody for PGHS-2 (cat\# 160106) and PGHS-2 blocking peptide (cat\# 360106; Cayman Chemicals, Ann Arbor, MI); biotin conjugated antirabbit IgG (cat\# sc-2040; Santa Cruz Biotechnology); normal horse serum, biotinylated horse antimouse IgG, horseradish peroxidase-avidin-biotin complex, 3, 3'-diaminobenzidine (DAB kit; Vectastain; Vector Laboratories, Burlingame, CA); enhanced chemiluminescence (ECL) kit (Renaissance Western Blot Chemiluminescence Reagent Plus; NEN Life Science Products, Boston, MA); ultrasensitive hybridization buffer (ULTRAhyb; cat\# 8670; Ambion Inc., Austin, TX); dCTP $\alpha{ }^{3}{ }^{32} \mathrm{P}$ (cat\# 33004x01), Biotrans nylon membrane (ICN, Irvine, CA); nitrocellulose membrane (Hybond-ECL); isotopically labeled $\left[5,6,8,11,12,14,15-{ }^{3} \mathrm{H}\right]-\mathrm{PGF}_{2 \alpha}$ and $\mathrm{PGE}_{2}$; 
Table 1. Forward $(\mathrm{F})$ and reverse $(\mathrm{R})$ oligonucleotide primers for cloning bovine oxytocin receptor (OTR), progesterone receptor (PR), and prostaglandin E synthase (PGES) cDNA.

\begin{tabular}{llll}
\hline cDNA & Primer set & $\begin{array}{l}\text { Size } \\
(\mathrm{bp})\end{array}$ & $\begin{array}{l}\text { GenBank } \\
\text { accession } \\
\text { number }\end{array}$ \\
\hline OTR & F 5' GCACCTGAGCATAGCCGACC 3' & 397 & AF101724 \\
& R 5'GTGGCAAGGACGATGACGGG 3' & & \\
PR & F 5' TCTGGAAATTCAACACTCAG 3' & 291 & AY116891 \\
& R 5' GCTTCAAGTCAGCCAAGAAG 3' & & \\
PGES & F 5' GCGCGCTGCTGGTCATCAAA 3' & 314 & AY032727 \\
& R 5' GTGTAGGCCAGGGAGCGGGT 3' & & \\
\hline
\end{tabular}

horseradish peroxidase-linked antimouse IgG (NA931V) and antirabbit IgG (NA934V; Amersham Biosciences Corp., Piscataway, NJ). All other materials were from Fisher Scientific (Pittsburgh, PA) and Sigma Chemical Co. (St. Louis, MO).

\section{Animals and Experimental Design}

Estrus in nonlactating multiparous Holstein cows ( $\mathrm{n}=78$ ) was synchronized with a modified Presynch + Ovsynch protocol (DeJarnette and Marshall, 2003; Bilby et al., 2004) and timed AI $(\mathrm{n}=55)$ or not timed AI $(n=23)$ on d 0 (day of preovulatory surge of lutenizing hormone induced by GnRH). Cows received bST (500 $\mathrm{mg}$ ) or no bST on d0 and 11 , and were slaughtered on d 17 (Bilby et al., 2004). Reproductive tracts were collected from 14 cycling (7 non bST-treated [C] and 7 bST-treated [bST-C]) and 16 pregnant (7 non bSTtreated $[\mathbf{P}]$ and 9 bST-treated [bST-P]) cows. Endometrial tissues were collected from a subsample of 30 normal cows at slaughter that had ovulated in response to the Ovsynch protocol, and were cyclic or pregnant at $d$ 17 (Bilby et al., 2004). Conceptuses and uterine secretions were recovered as described by Lucy et al. (1995). Briefly, $40 \mathrm{~mL}$ of PBS was injected into the uterine horn contralateral to the CL from the uterotubal junction and massaged gently through the horn ipsilateral to the CL. Flushing media and conceptus were recovered through an incision in the ipsilateral horn. Endometrial tissue from the antimesometrial border of the ipsilateral horn was cut $(1 \times 1 \mathrm{~cm})$ and frozen in liquid nitrogen for Western and Northern blots, or fixed in $4 \%$ paraformaldehyde for immunohistochemistry.

\section{RNA Isolation and Northern Blotting}

Total RNA was isolated from endometrial tissues $(\mathrm{n}=$ 30) with Trizol according to manufacturer's specifications. Total RNA (30 $\mu \mathrm{g})$ was electrophoresed in $1 \%$ agarose-formaldehyde gels and blotted to nylon membranes. Membrane RNA was crosslinked by UV radia- tion and baked at $80^{\circ} \mathrm{C}$ for $1 \mathrm{~h}$. Probes were obtained using a reverse transcription-PCR procedure. Complementary DNA was reverse-transcribed from total RNA $(5 \mu \mathrm{g})$ prepared from the bovine CL following the manufacturer's protocol with the cDNA Cycle kit. A set of primers (forward and reverse; Table 1) was synthesized on published sequences from bovine OTR (Bathgate et al., 1995). Primers for PR were designed using conserved sequences for ovine (Ing et al., 1996) and porcine PR (Iwai et al., 1991) mRNA, and as a result, we reported a partial coding sequence for bovine PR (Table 1). A set of primers was synthesized based on conserved sequences from PGES (Fillion et al., 2001) mRNA (Table 1).

The primers were used in PCR amplification using an Eppendorf Mastercycler Gradient Thermocycler (Eppendorf Scientific Inc., Westborg, NY) in a total reaction volume of $50 \mu \mathrm{L}$ containing $1 \mu \mathrm{L}$ of cDNA template, $300 \mathrm{ng}$ of each primer, $10 \mathrm{n} M \mathrm{dNTP}, 1 \times$ PCR buffer ( 2 $\mathrm{m} M \mathrm{MgCl}_{2}, \mathrm{pH} 9.0$ ), and 1 unit of Taq polymerase. The PCR products were electrophoresed in 1.5\% agarose gels, and cDNA fragments of the expected size were subcloned into TOPO vector. The nucleotide sequences of the generated clones were determined at the nucleotide sequencing facility of the Interdisciplinary Center for Biotechnology Research of the University of Florida, and were compared with respective gene sequences reported in GenBank. The ER $\alpha$ cDNA was a gift from $\mathrm{N}$. H. Ing (Texas A\&M University, College Station, Texas). The PGFS (Xiao et al., 1998) and PGHS-2 (Liu et al., 2001) cDNA were a gift from J. Sirois (University of Montreal, St. Hyacinthe, Canada).

The blots were prehybridized with ULTRAhyb buffer for $1 \mathrm{~h}$ at $42^{\circ} \mathrm{C}$ and hybridized with random-primed ${ }^{32}$ P-labeled probes (ER $\alpha$, OTR, PR, PGHS-2, PGES, PGFS, and glyceraldehyde-3-phosphate dehydrogenase) overnight at $42^{\circ} \mathrm{C}$. The next day, the blots were washed in $2 \times$ saline sodium citrate/0.1\% SDS and twice in $0.1 \times$ saline sodium citrate/0.1\% SDS for $20 \mathrm{~min}$ each at $42^{\circ} \mathrm{C}$. The blots were then exposed to $\mathrm{x}$-ray film at $-80^{\circ} \mathrm{C}$. The autoradiographs were quantified using densitometry.

\section{Immunohistochemical Analyses}

Paraffin sections $(5 \mu \mathrm{m})$ from the antimesometrial border of the uterus from 22 cows (5 C, 6 P, 7 bST-C, and 4 bST-P) were prepared. Immunohistochemistry was used to visualize ER $\alpha$, PR, and PGHS-2 immunostaining as described previously (Wang et al., 1999). After deparaffinization, an antigen retrieval procedure was performed by heating sections in a microwave oven at high power for $5 \mathrm{~min}$ in $0.01 \mathrm{M}$ sodium citrate buffer (pH 6.0). Sections were allowed to cool for $20 \mathrm{~min}$, and 
were then washed in $0.01 M$ PBS (pH 7.5). Nonspecific endogenous peroxidase activity was blocked by treatment with $3 \%$ hydrogen peroxide in methanol for 10 min at room temperature. After a 10-min wash in PBS, nonspecific binding was blocked using 1.5\% (vol/vol) normal horse serum in PBS in a humidified chamber at room temperature for $30 \mathrm{~min}$. Tissue sections were incubated for $60 \mathrm{~min}$ at room temperature with the primary antibody (diluted 1:25 in $\mathrm{PBS}$ for $\mathrm{ER} \alpha$, and 1:100 for PR and PGHS-2). Nonimmune serum at equivalent concentrations were used as negative controls for $\mathrm{ER} \alpha$ and PR. Negative controls for PGHS-2 were obtained by preincubation of primary antibody with PGHS-2 peptide at 1:10 (vol/vol) ratio for $1 \mathrm{~h}$. After primary antibody binding, the sections were incubated for $60 \mathrm{~min}$ at room temperature with a biotinylated horse antimouse IgG (for ER $\alpha$ and PR) or horse antirabbit IgG (for PGHS-2) diluted 1:200 (vol/vol) in normal horse serum. Thereafter, tissue sections were incubated for $60 \mathrm{~min}$ at room temperature with a horseradish avidin-biotin-peroxidase complex. Site of the bound enzyme was visualized by the application of $3,3^{\prime}$-diaminobenzidine in $\mathrm{H}_{2} \mathrm{O}_{2}$. Sections were counterstained with hematoxylin and dehydrated before they were mounted with Permount.

\section{Microscopic Image Analysis}

Subjective image analysis was performed to estimate the relative abundance of $\mathrm{ER} \alpha, \mathrm{PR}$, and PGHS-2 staining in different cell types. Two independent evaluators assessed immunostaining in 10 randomly selected fields of intercaruncular endometrium in 3 pieces of endometrium from each cow. Caruncular endometrium was not evident in all cows. Five uterine compartments were evaluated: luminal epithelium, superficial glandular epithelium (close to the uterine lumen), deep glandular epithelium (close to the myometrium), superficial intercaruncular stroma (just beneath the luminal epithelium layer) and deep intercaruncular stroma (between the superficial stroma and the myometrium). Because specific staining for PGHS-2 protein was detectable exclusively in the cytoplasm of endometrial luminal epithelial cells, only those cells were scored. Intensity of staining was scored on a 4-point scale, where $0=$ no staining (no brown), $1=$ less (light brown), $2=$ moderate (brown), and 3 = heavy (dark brown); the staining intensities were expressed as the percentage of positively stained cells for each point on the scale (Boos et al., 2000). Average staining for each field was calculated as follows: ( 0 [no brown] $\times \mathrm{N}+1$ [less brown] $\times \mathrm{N}+2$ [moderate brown] $\times \mathrm{N}+3$ [heavy brown] $\times \mathrm{N}$ )/ 100 , where $\mathrm{N}$ is percentage of staining.

\section{Western Blotting for ER $\alpha$ and PGHS-2 Proteins}

Endometrial tissue $(300 \mathrm{mg})$ from 30 cows was sonicated 3 times for $5 \mathrm{~s}$ each in $2 \mathrm{~mL}$ of whole cell extract buffer (50 m $M$ Tris, $\mathrm{pH} 8.0,300 \mathrm{~m} M \mathrm{NaCl}, 20 \mathrm{~m} M \mathrm{NaF}$, $1 \mathrm{~m} M \mathrm{Na}_{3} \mathrm{VO}_{4}, 1 \mathrm{~m} M \mathrm{Na}_{4} \mathrm{P}_{2} \mathrm{O}_{7}, 1 \mathrm{~m} M$ EDTA, $1 \mathrm{~m} M$ ethylene glycol-bis[ $\beta$-aminoethyl ether]-N N N'N'-tetraacetic acid (EGTA), $0.5 \mathrm{~m} M$ phenylmethylsulfonyl fluoride, $10 \% \mathrm{vol} / \mathrm{vol}$ glycerol, $1 \% \mathrm{vol} / \mathrm{vol}$ Nonidet P-40, and $10 \mu \mathrm{g} / \mathrm{mL}$ each of aprotinin, leupeptin, and pepstatin). Lysates were processed by centrifugation (14,000 $\times \mathrm{g}$ for $10 \mathrm{~min}$ ), and protein concentrations determined in supernatants (Bradford, 1976). Volumes of whole cell extract from each cow corresponding to $200 \mu \mathrm{g}$ of protein were loaded onto 7.5\% denaturing (for $\mathrm{ER} \alpha$ ) or nondenaturing (for PGHS-2) acrylamide gels, submitted to SDS-PAGE, and electrophoretically transferred to nitrocellulose membranes. Membranes were blocked for 2 $\mathrm{h}$ in 5\% (wt/vol) NDM in Tris-buffered saline containing $0.1 \%$ Tween-20 (TBST), washed for $15 \mathrm{~min}$ in TBST, and probed with mouse $\mathrm{ER} \alpha$ antibody (1:1000) or rabbit PGHS-2 antibody (1:500) diluted in 5\% NDM in TBST for $2 \mathrm{~h}$. Secondary antibodies were HRP-conjugated antimouse IgG or antirabbit IgG (1:5000 dilutions in 5\% NDM in TBST). Proteins were detected using a chemiluminescent substrate and analyzed by densitometry (Alpha lmager 2000).

\section{Radioimmunoasssay}

Concentrations of $\mathrm{PGF}_{2 \alpha}$ and $\mathrm{PGE}_{2}$ were measured in uterine flushings by direct radioimmunoassay as described by Danet-Desnoyers et al. (1994) and Gross et al. (1988), respectively. Both antisera were characterized by Dubois and Bazer (1991). The antiPGF ${ }_{2 \alpha}$ antiserum was diluted 1:5000 and the antiPGE $\mathrm{F}_{2}$ antiserum was diluted 1:1000 in Tris buffer. Intraassay coefficients of variation for $\mathrm{PGF}_{2 \alpha}$ and $\mathrm{PGE}_{2}$ assay were 13.3 and $2.9 \%$, respectively.

\section{Statistical Analyses}

Data generated from immunohistochemistry of $\mathrm{ER} \alpha$, PR, and PGHS-2 were analyzed by the mixed model procedure of SAS (SAS Inst. Inc., Cary, NC) for each type of cell. The model included treatment (C, P, bST$\mathrm{C}$, and bST-P), evaluator, and treatment $\times$ evaluator interaction. Cow within treatment was the error term used to test for treatment effects and evaluator $\times$ cowwithin-treatment was used as the error term to test the effects of evaluator and treatment $\times$ evaluator. In the case of glandular epithelium, 2 different evaluation sites were used (superficial and deep), so for glandular epithelium staining, the model included main effects of treatment, evaluator, site, and higher order interac- 


\section{DAY 17 DAY 0}



Figure 1. Representative Northern blot of oxytocin receptor (OTR) mRNA in endometrium of cows at d 17 after estrus. Thirty micrograms of total RNA from 30 cows (7 cyclic, 7 pregnant, 7 bST-treated cyclic, and 9 bST-treated pregnant) was fractionated and hybridized with radiolabeled OTR cDNA. Four transcripts of OTR mRNA were detected from endometrium of a cow at estrus (d 0). The most prominent 5.6-kb transcript of OTR mRNA at d 17 was evaluated for further analysis in all 30 cows.

tions. A series of orthogonal contrasts were constructed to test effects of bST, pregnancy status, and bST $\times$ pregnancy status.

Abundances of ER $\alpha$ and PGHS-2 proteins in Western blots as well as ER $\alpha$, PR, OTR, PGFS, PGES, and PGHS-2 mRNA in Northern blots were analyzed using the least square ANOVA procedure of SAS. Main effects of treatment (C, P, bST-C, bST-P), gel, and treatment $\times$ gel were examined, and for mRNA responses, band intensities of glyceraldehyde-3-phosphate dehydrogenase mRNA were used as a covariate to adjust for loading differences. Treatment $\times$ gel effects were not significant. Predesigned orthogonal contrasts were used to compare treatment means (bST, pregnancy status, and bST $\times$ pregnancy status).

Total contents of $\mathrm{PGF}_{2 \alpha}$ and $\mathrm{PGE}_{2}$ in uterine flushings were analyzed using the GLM procedure of SAS. The model included the main effect of treatment $(\mathrm{C}, \mathrm{P}$, bST-C, bST-P) and orthogonal contrasts were constructed to test treatment means (pregnancy status, bST, and pregnancy status $\times$ bST interaction).

\section{RESULTS}

\section{Total Contents of $\mathrm{PGF}_{2 \alpha}$ and $\mathrm{PGE}_{2}$ in Uterine Flushings in Cyclic and Pregnant Cows}

Pregnancy rates were decreased $(P<0.01)$ in cows by bST $(27.2 \%$; 9 of 33$)$ compared with nonbST treatment
(63.6\%; 14 of 22 ; Bilby et al., 2004). Volumes of recovered flushing fluids did not differ in response to pregnancy status or bST treatment. Total $\mathrm{PGF}_{2 \alpha}(619 \pm 66$ vs. $109 \pm 36 \mathrm{ng} ; P<0.01)$ and $\mathrm{PGE}_{2}(86 \pm 9$ vs. $12 \pm 5$ $\mathrm{ng}, P<0.01)$ contents were greater in uterine flushings of $\mathrm{P}$ cows compared with $\mathrm{C}$ cows, respectively. Treatment with bST had no effect on uterine PG content.

\section{Endometrial Oxytocin Receptor Expression}

Four transcripts of OTR $(5.6,3.3,2.1$, and $1.5 \mathrm{~kb})$ were detected in endometrial tissue from a cow in estrus (Figure 1). All 4 transcripts were present at relatively low levels in endometrial tissue on $\mathrm{d} 17$, and the most prominent $(5.6 \mathrm{~kb})$ transcript was quantified. Steady state concentrations of OTR mRNA were greater $(P<$ $0.01)$ in bST-treated cows, and the interaction of bST $\times$ pregnancy status indicated that the OTR mRNA steady state concentration was greater in bST-C cows than in bST-P cows (Table 2).

\section{Endometrial ER $\alpha$ Expression}

A 6.8-kb ER $\alpha$ mRNA transcript of the same size as that observed in sheep (Ing et al., 1996) and cattle (Meikle et al., 2001) was detected in the endometrium at d 17. Steady state concentrations of $\mathrm{ER} \alpha \mathrm{mRNA}$ in endometrial tissues were reduced in $\mathrm{P}$ cows $(P<0.01)$ and in bST-P cows $(P<0.05$; Table 2$)$. 
Table 2. Least square means and pooled SE for uterine endometrial expression responses at d 17 after estrus in nonlactating cyclic or pregnant dairy cows injected with bST on d 0 and 11 after estrus. Arbitrary units (AU) were generated by densitometry and mRNA results are adjusted for glyceraldehyde-3-phosphate dehydrogenase as a covariate.

\begin{tabular}{|c|c|c|c|c|c|c|c|c|}
\hline \multirow[b]{3}{*}{ Response $^{2}$} & \multirow{2}{*}{\multicolumn{4}{|c|}{ Treatments $^{1}$}} & \multirow[b]{3}{*}{$\mathrm{SE}$} & \multicolumn{3}{|c|}{ Contrasts } \\
\hline & & & & & & Pregnancy & & Status \\
\hline & $\mathrm{C}$ & $\mathrm{P}$ & bST-C & bST-P & & status & $\mathrm{bST}$ & $\times \mathrm{bST}$ \\
\hline OTR mRNA, AU & 108 & 111 & 150 & 129 & 5.7 & NS & $* *$ & * \\
\hline ER $\alpha$ mRNA, AU & 156 & 149 & 152 & 131 & 4.6 & $* *$ & $*$ & NS \\
\hline $\mathrm{ER} \alpha$ protein, $\mathrm{AU}$ & 161 & 130 & 176 & 149 & 9.6 & $* *$ & $\dagger$ & NS \\
\hline $\mathrm{ER} \alpha$ lumen, $\mathrm{SA}^{3}$ & 1.71 & 1.40 & 1.54 & 1.34 & 0.10 & $*$ & NS & NS \\
\hline PR mRNA, AU & 137 & 140 & 147 & 147 & 1.3 & NS & $* *$ & NS \\
\hline PR gland, $\mathrm{SA}^{3}$ & 1.25 & 1.91 & 1.44 & 1.64 & 0.11 & $* *$ & NS & $\dagger$ \\
\hline $\mathrm{PR}$ stroma, $\mathrm{SA}^{3}$ & 1.27 & 1.30 & 0.85 & 1.02 & 0.15 & NS & $*$ & NS \\
\hline
\end{tabular}

$\dagger P=0.10$.

$* P=0.05$.

$* * P=0.01$.

${ }^{1} \mathrm{C}=$ Cyclic; $\mathrm{P}$ = pregnant; bST-C = bST-cyclic; bST-P = bST-pregnant.

${ }^{2} \mathrm{OTR}=$ Oxytocin receptor; $\mathrm{ER} \alpha=$ estradiol receptor $\alpha$; PR = progesterone receptor.

${ }^{3}$ Staining intensity weighted average (SA) for luminal ER $\alpha$, and glandular or stromal PR proteins $(0=$ none, $1=$ less, 2 = moderate, and $3=$ heavy staining) in 22 cows.

Pregnancy induced a decrease in $\mathrm{ER} \alpha$ protein in the endometrium $(P<0.01$; Table 2$)$, as detected by Western blotting. Interestingly, bST stimulated steady state concentrations of $\mathrm{ER} \alpha$ protein in the endometrium of $\mathrm{C}$ and $\mathrm{P}$ cows $(P=0.08$; Table 2$)$.

Immunohistochemistry was used to localize $\mathrm{ER} \alpha$ in the endometrium, and staining was detected exclusively in the nuclei of epithelial and stromal cells (Figure 2). When monoclonal specific antibody was substituted with a mouse IgG, the absence of staining (Figure 2A) demonstrated the specificity of antibody to ER $\alpha$. Pregnancy decreased abundance of $\mathrm{ER} \alpha$ in luminal epithelium $(P<0.05$; Table 2$)$. The changes were reflected in pregnant cows as an increase $(P<0.01)$ in the percentage of cells exhibiting less staining intensity and a decrease $(P<0.01)$ in heavy staining intensity.

\section{Endometrial PR Expression}

A 4.3-kb PR mRNA transcript was detected in the endometrium at d 17 after GnRH. Meikle et al. (2001) reported a major transcript of $4.3 \mathrm{~kb}$ in bovine endometrium using human-derived cDNA probes. Treatment with bST increased $(P<0.01)$ steady state concentrations of PR mRNA in endometrial tissue (Table 2).

Immunohistochemical staining was seen exclusively in the nuclei of epithelial and stromal cells (Figure 2E and F). When monoclonal specific antibody was substituted with a mouse IgG, staining was absent (Figure $2 \mathrm{D})$. Within the endometrial tissue, pregnancy increased $(P<0.01)$ the average staining for PR protein in superficial and deep endometrial glands (Table 2). A bST $\times$ pregnancy status interaction $(P=0.06)$ was detected, in which the pregnancy-induced increase in PR expression in the glands was of a lower magnitude in bST-treated cows. However, in the stromal layer of the endometrium, bST decreased $(P<0.05) \mathrm{PR}$ protein abundance regardless of the cyclic-pregnant status (Table 2). The luminal epithelium was devoid of positive staining, other than in 2 cows.

\section{Endometrial PGHS-2 Expression}

A 4.4-kb transcript of PGHS-2, as shown by Liu et al. (2001), and a specific band of $72 \mathrm{kDa}$ for PGHS-2 protein were detected in all samples of endometrium at d 17 following GnRH. No differences were detected in steady state concentrations of PGHS-2 mRNA due to pregnancy or bST treatments (Table 3). There was an increase in PGHS-2 protein in response to pregnancy $(P<0.01)$ and bST $(P<0.05)$ treatments as detected by Western blotting (Table 3).

Immunohistochemistry was used to localize PGHS2 protein in the endometrium, and staining was substantial in the cytoplasm of endometrial luminal epithelial cells (Figure $2 \mathrm{H}$ and I). When primary antibody was first incubated with PGHS-2 blocking peptide, the absence of staining demonstrated the specificity for PGHS-2 (Figure 2G). Some light staining was detected in the glandular epithelium and subepithelial stroma. However, the staining in these types of cells was inconsistent and not evaluated. Pregnancy increased $(P<$ $0.05)$ the intensity of staining for PGHS-2 protein in luminal epithelial cells (Table 3 ). No detectable changes in staining intensity for PGHS-2 in the luminal epithelium were observed in response to bST treatments. 


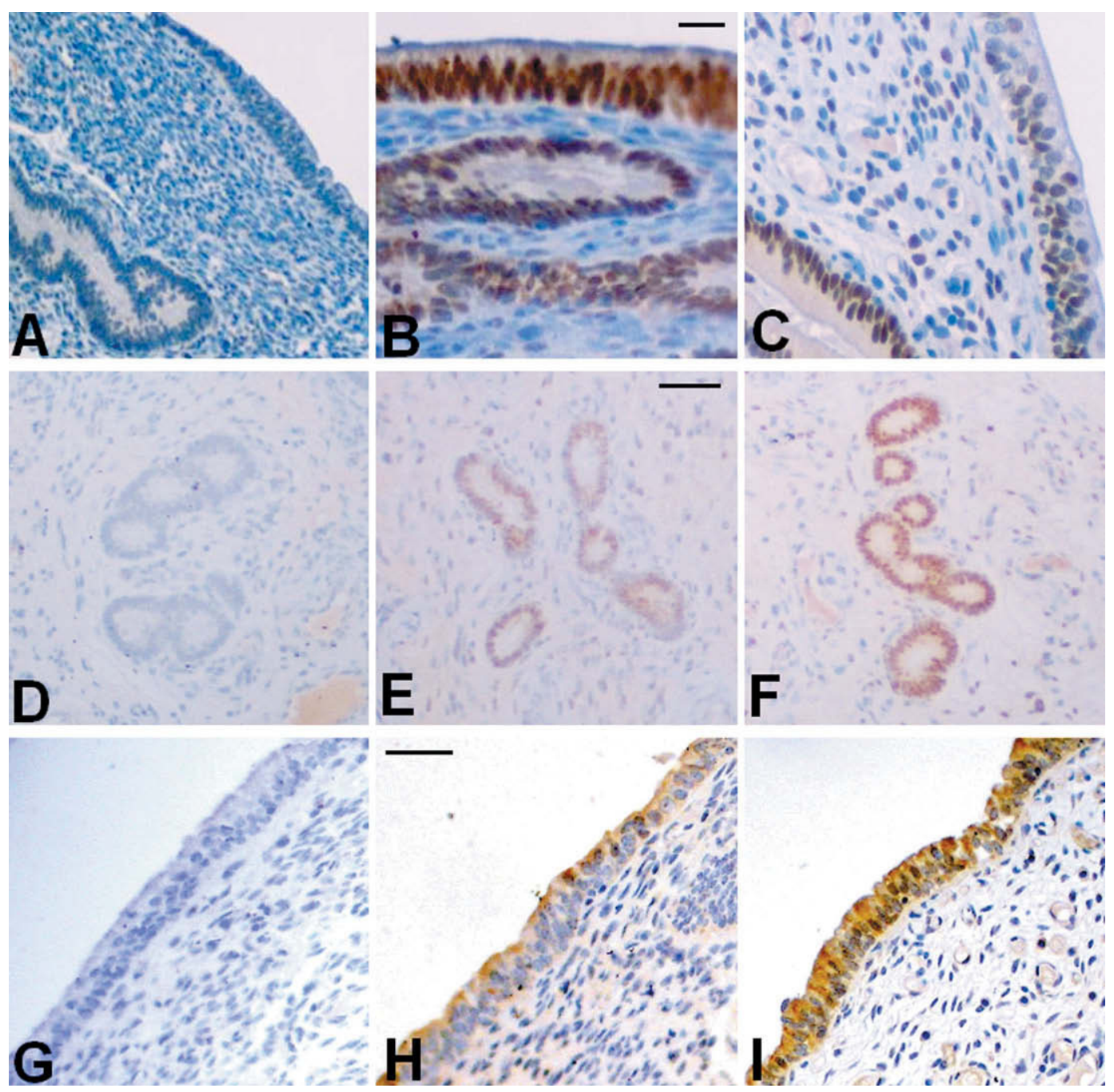

Figure 2. Expression of estradiol receptor $\alpha(\mathrm{ER} \alpha)$, progesterone receptor (PR), and prostaglandin H synthase-2 (PGHS-2) in bovine endometrium at $\mathrm{d} 17$ of the estrous cycle. No immunopositive staining was detected when primary antibody was replaced by mouse IgG (A for ER $\alpha$ and D for PR) and when primary antibody was first incubated with PGHS-2 blocking peptide (G for PGHS-2). Staining for ER $\alpha$ and PR was detected exclusively in the nuclei of the epithelial and stroma cells. Pregnancy $(\mathrm{C})$ decreased $(P<0.05)$ abundance of ER $\alpha$ in the luminal epithelium compared with the cycle $(\mathrm{B})$ and increased $(P<0.01) \mathrm{PR}$ staining in the glandular epithelium $(\mathrm{F})$ compared with the cycle (E). Staining for PGHS-2 was observed in the cytoplasm of endometrial luminal epithelial cells. Pregnancy (I) increased $(P<$ 0.05 ) the intensity of staining for PGHS-2 protein in the luminal epithelial cells compared with the cycle (H). Bars equal: $0.250 \mathrm{~mm}$ at $40 \times$, $0.150 \mathrm{~mm}$ at $66 \times$, and $0.125 \mathrm{~mm}$ at $80 \times$. A, D, E, and F: 40×; G, H, and I: 66×; B and C: 80×.

\section{Endometrial PGFS and PGES mRNA Expression}

Transcripts of $1.3 \mathrm{~kb}$ for PGES (Arosh et al., 2002) and $1.4 \mathrm{~kb}$ for PGFS (Xiao et al., 1998) were detected in the endometrium at $\mathrm{d} 17$ after $\mathrm{GnRH}$. Relative steady state concentrations of PGFS and PGES mRNA did not differ between treatments although PGES mRNA tended $(P<0.10)$ to be greater in bST-treated cows (Table 3).

\section{DISCUSSION}

Differential regulation of $P G$ secretion in cyclic and pregnant animals is pivotal to our understanding of pregnancy and the endometrial response to factors such as bST that appear to improve fertility. It is clear that in nonlactating multiparous dairy cows treated with bST, pregnancy rates were decreased (Bilby et al., 2004). It is important to recognize that, in addition to using experimental cows that were not lactating, cows were injected twice with bST, $11 \mathrm{~d}$ apart. This was done to ensure that there was sustained bST exposure for the entire 17-d period to slaughter. In lactating cows treated with bST (500 mg of Posilac at 2-wk intervals), fertility was increased (Moreira et al., 2001). Thus, it is possible that overstimulation with bST, due to a standard dose of bST given to nonlactating cows $11 \mathrm{~d}$ apart, 
Table 3. Least square means and pooled standard error (SE) for uterine endometrial expression response at d 17 after estrus in nonlactating cyclic or pregnant dairy cows $(n=30)$ injected with bST on d 0 and 11 after estrus. Arbitrary units (AU) were generated by densitometry and mRNA results are adjusted for glyceraldehyde-3-phosphate dehydrogenase as a covariate.

\begin{tabular}{|c|c|c|c|c|c|c|c|c|}
\hline \multirow[b]{3}{*}{ Response $^{2}$} & \multirow{2}{*}{\multicolumn{4}{|c|}{ Treatment $^{1}$}} & \multirow[b]{3}{*}{$\mathrm{SE}$} & \multicolumn{3}{|c|}{ Contrasts } \\
\hline & & & & & & Preonancy & & Status \\
\hline & $\mathrm{C}$ & $\mathrm{P}$ & bST-C & bST-P & & status & bST & $\times \mathrm{bST}$ \\
\hline PGHS2 mRNA, AU & 166 & 176 & 171 & 164 & 11 & NS & NS & NS \\
\hline PGHS-2 protein, AU & 44 & 70 & 57 & 97 & 9.4 & ** & $*$ & NS \\
\hline PGHS-2 lumen, $\mathrm{SA}^{3}$ & 1.58 & 1.87 & 1.77 & 1.91 & 0.1 & $*$ & NS & NS \\
\hline PGFS mRNA, AU & 127 & 129 & 125 & 128 & 5.9 & NS & NS & NS \\
\hline PGES mRNA, AU & 136 & 129 & 138 & 137 & 3 & NS & $\dagger$ & NS \\
\hline
\end{tabular}

$\dagger P=0.10$.

$* P=0.05$.

$* * P=0.01$.

${ }^{1} \mathrm{C}=$ Cyclic, $\mathrm{P}=$ pregnant, bST-C = bST-cyclic, bST-P = bST-pregnant.

${ }^{2}$ PGHS-2 = Prostaglandin $\mathrm{H}$ synthase-2; PGFS = prostaglandin $\mathrm{F}$ synthase; $\mathrm{PGES}=$ prostaglandin $\mathrm{E}$ synthase.

${ }^{3}$ Staining intensity weighted average (SA) for luminal estradiol receptor $\alpha$, glandular, and stromal progesterone receptor proteins $(0=$ none, $1=$ less, $2=$ moderate, and $3=$ heavy staining $)$.

may have distinct physiological effects that contributed to a reduction in fertility.

In the present study, we examined effects of pregnancy and bST on steady state concentrations of mRNA and their respective proteins $(\mathrm{ER} \alpha, \mathrm{PR}, \mathrm{OTR}$, and PGHS-2 proteins) in the uterine endometrium that are known to be modulated by the estrous cycle and pregnancy. At $\mathrm{d} 17$ of the cycle, the potential luteolytic cascade was affected as pregnancy decreased steady state concentrations of ER $\alpha$ and OTR mRNA in bST-treated cows and increased concentration of PGHS-2 protein in all pregnant cows. A decline in the concentrations of $\mathrm{ER} \alpha$ and OTR could have an attenuatory effect on the pulsatile secretion of $\mathrm{PGF}_{2 \alpha}$ by endometrium that initiates luteolysis; increased PGHS-2 could contribute to the greater basal concentrations of 13, 14-dihydro 15keto PGF $_{2 \alpha}$ (PGFM) in the circulation (Williams et al., 1983; Mishra et al., 2003) and uterine secretions.

In our study, pregnant cows had much higher concentrations of $\mathrm{PGF}_{2 \alpha}$ and $\mathrm{PGE}_{2}$ in uterine flushings than cyclic animals. Others also have reported a greater prostaglandin content in uterine flushings from pregnant than cyclic cattle on 16 and 19 postestrus (Lewis et al., 1982; Bartol et al., 1985). Conceptuses recovered from those cattle were able to convert radiolabeled arachidonic acid into prostaglandins (Lewis et al., 1982). The trophoblastic cells of the ovine conceptus highly expressed PGHS-2 protein during d 10 to 17 of gestation (Charpigny et al., 1997a). Thus, high luminal content of $\mathrm{PG}$ in pregnant ruminants may be, in part, because of production and release by the conceptus.
In the endometrium, PGHS-2 protein was localized consistently to the luminal epithelium. This observation is consistent with previous reports, although others have suggested there is some stromal expression (Charpigny et al., 1997b; Boos, 1998; Kim et al., 2003). Endometrial expression of PGHS-2 mRNA did not differ in response to pregnancy or bST treatments, but PGHS-2 protein was increased by pregnancy and bST treatment. The increase in pregnancy was detected both by immunocytochemistry and Western blotting. Emond et al. (2004) reported that endometrial expression of PGHS2 protein was increased during early pregnancy and in response to intrauterine infusions of IFN- $\tau$. Arosh et al. (2002) showed that the PGHS-2 protein concentrations peaked around d 16 to 18 of the cycle without any changes in PGHS-2 mRNA concentrations. In sheep, PGHS-2 mRNA levels were similar in cyclic and pregnant ewes, although PGHS-2 protein expression was maintained at greater levels in pregnant ewes than cyclic ewes after about d 15 (Salamonsen and Findlay, 1990; Charpigny et al., 1997b). In contrast, PGHS-2 mRNA expression was found to be greater in pregnant ewes between $\mathrm{d} 10$ and 18 , with concentrations decreasing by d 16 in cyclic ewes (Kim et al., 2003). Collectively, these findings are consistent with an upregulation of endometrial PGHS-2 protein during pregnancy, and support the hypothesis of Charpigny et al. (1997b) that pregnancy may be associated with increased translation efficiency or increased stability of PGHS-2 protein in the absence of changes in steady state concentrations of PGHS-2 mRNA, or both. Interestingly, this increased expression of PGHS-2 protein in the endometrium of 
early pregnancy could explain the greater basal concentrations of PGFM reported in pregnant cows (Williams et al., 1983), pregnant ewes (Zarco et al., 1988; Payne and Lamming, 1994), and pregnant water buffalo (Mishra et al., 2003). However, increased basal concentrations of PGFM reflects a secretion pattern that is not luteolytic or pulsatile in nature (Thatcher et al., 1984). An absence of luteolytic pulses, but greater basal concentrations of plasma PGFM indicate that pregnancy does not completely suppress the endometrium's ability to synthesize prostaglandins, but alters the pattern of secretions.

Therefore, it is important to determine the responses of PGFS and PGES mRNA (i.e., relative gene expression that may or may not be related to enzymatic protein and activity) regarding potential downstream metabolism of $\mathrm{PGH}_{2}$. It is hypothesized that downstream metabolism of $\mathrm{PGH}_{2}$ to $\mathrm{PGF}_{2 \alpha}$ could be decreased, or conversion of $\mathrm{PGH}_{2}$ into $\mathrm{PGE}_{2}$ increased, because luteolytic peaks of $\mathrm{PGF}_{2 \alpha}$ are reduced in pregnancy. Relative expression of PGFS mRNA did not differ due to pregnancy status or bST treatment. No evidence exists for an upregulation of PGES mRNA in early pregnancy, although PGES mRNA was numerically greater in bSTtreated cows $(P<0.10)$. Collectively, the present responses suggest that inhibition of luteolytic pulses of $\mathrm{PGF}_{2 \alpha}$ is not regulated directly through regulation in expression of the components comprising the prostaglandin synthesis cascade.

Pulsatile secretion of $\mathrm{PGF}_{2 \alpha}$ from endometrial tissue is thought to be dependent upon an increase in OTR concentration within the luminal epithelium (McCracken et al., 1999). In the present study, pregnancy induced a decrease in steady state concentrations of OTR mRNA in the bST-P compared with bST-C cows. In sheep and cattle, an upregulation of OTR is inhibited by pregnancy, likely due to secretion of IFN- $\tau$ by the conceptus (Farin et al., 1990). The OTR is undetectable in the bovine endometrium during much of the luteal phase, but increases on or after d 15 of the estrous cycle (Fuchs et al., 1990; Mann and Lamming, 1994; Robinson et al., 1999, 2001). On d 17, at the time of expected initiation of luteolysis, OTR concentrations were about $10 \%$ of what was seen during estrus (Fuchs et al., 1990). Injection of oxytocin into nonpregnant cows induced the release of $\mathrm{PGF}_{2 \alpha}$ on $\mathrm{d} 16$ (Lamming and Mann, 1995). These findings indicate that only subtle increases of OTR concentration are needed to induce a luteolytic release of $\mathrm{PGF}_{2 \alpha}$.

No difference in OTR steady state mRNA levels were detected between $\mathrm{C}$ and $\mathrm{P}$ cows that were not treated with bST, whereas OTR mRNA levels were greater in
bST-C than bST-P cows. Treatment with bST may have advanced the uterine environment, so that it is more like a d-18 or -19 uterus. Under these circumstances, pregnancy was able to block induction of the OTR mRNA in bST-treated cows.

The decrease in the OTR mRNA concentration in bST-P cows may be due to a concurrent decrease in $\mathrm{ER} \alpha$ mRNA and protein expression in pregnant cows. Regardless of bST-treatment, $C$ cows had increased concentrations of ER $\alpha$ mRNA and protein. Immunohistochemistry indicated that the luminal epithelium of the endometrium of $\mathrm{C}$ cows had the greatest levels of the $\mathrm{ER} \alpha$ receptor. Similarly, an upregulation of $\mathrm{ER} \alpha \mathrm{mRNA}$ and protein in the luminal epithelium was detected around $d 14$ to 16 of the estrous cycle in C cows, whereas expression was very low in $\mathrm{P}$ cows at the same stage (Kimmins and MacLaren, 2001; Robinson et al., 2001). Effects of bST on ER $\alpha$ expression were complex. Although bST treatment further reduced steady state concentrations of ER $\alpha$ mRNA in P cows, it had a stimulatory effect on ER $\alpha$ protein. Growth hormone treatment increased ER protein in guinea pig uterus and rat mammary gland (Bezecny et al., 1992; Feldman et al., 1999). On the other hand, Spencer et al. (1999) failed to detect any regulatory role of growth hormone on endometrial ER mRNA expression, or on PR and OTR gene expression in sheep.

Growth hormone may exert its effect indirectly through IGF-I, because bST treatment increased serum concentrations of IGF-I in cows (Bilby et al., 2004). Insulin-like growth factor-I increased ER expression in mammary and pituitary tumor cells (Newton et al., 1994; Lee et al., 1997). In other systems, IGF-I induces ER-dependent gene expression (Klotz et al., 2002). Endometrial IGF-I mRNA levels are increased during the bovine estrous cycle when circulating concentrations of estradiol are high (Meikle et al., 2001).

Treatment with bST stimulated PR mRNA accumulation in $\mathrm{d} 17$ bovine endometrium. Growth hormone treatments in ovariectomized ewes receiving ovarian steroid replacement therapy did not alter expression of PR in the uterus (Spencer et al., 1999). Observed upregulation of $\mathrm{ER} \alpha$ protein expression in response to bST treatment in the present experiment may have increased PR mRNA levels. Interestingly, bST decreased stromal PR expression.

Consistent with previous studies (Kimmins and MacLaren, 2001; Robinson et al., 2001), PR was localized mainly in the stroma and the glandular epithelium. In 2 of 10 cows, PR was detected in a small proportion of cells in the luminal epithelium. Pregnancy induced PR protein staining in superficial and deep glandular epithelia. This contrasts with previous reports of little or no glandular staining in the late luteal phase and 
early pregnancy (Kimmins and MacLaren, 2001; Robinson et al., 2001). In contrast, $P R$ protein was detected in the deep glands on d 16 in the bovine endometrium of pregnant cows (Robinson et al., 1999). Variable responses were reported in sheep (Spencer and Bazer, 1995; Zheng et al., 1996). These differences may be due to antibody selection. Traish and Wotiz (1990) tested 3 monoclonal antibodies raised against the $\mathrm{N}$-terminal domain, the DNA binding domain, or the ligand binding domain of the PR. The antibodies differed in binding to intact, partially degraded, or occupied PR. Such differences may contribute to the variable responses among studies.

The present study demonstrates that on d 17 after $\mathrm{GnRH}, \mathrm{ER} \alpha$ mRNA and protein concentrations were greater in cyclic than pregnant cows, regardless of whether cows received bST or not. The differential responses at d 17 suggest that downregulation of OTR mRNA due to pregnancy is associated with a decrease in $\mathrm{ER} \alpha$ mRNA expression and $\mathrm{ER} \alpha$ protein synthesis in bST-treated cows, as reported in sheep (Spencer et al., 1995).

Pregnancy-induced expression of PGHS-2 protein in the uterus might indicate that antiluteolytic action of IFN- $\tau$ to suppress secretion of $\mathrm{PGF}_{2 \alpha}$ is unlikely at the level of PGHS-2 expression. A decline in the concentrations of $\mathrm{ER} \alpha$ mRNA, ER $\alpha$ protein, and OTR mRNA of bST-treated pregnant cows may have caused a suppressive effect on pulsatile secretion of $\mathrm{PGF}_{2 \alpha}$ by endometrium that normally initiates luteolysis. The increase in PGHS-2 protein of pregnancy could contribute to the greater basal concentrations of $\mathrm{PGF}_{2 \alpha}$ in the circulation of pregnancy (Williams et al., 1983; Mishra et al., 2003). In early pregnancy, constant increases in production of IFN- $\tau$ by well-developed embryos would inhibit the luteolytic pulse generator for secretion of $\mathrm{PGF}_{2 \alpha}$. When poorly developed embryos produce small amounts of IFN- $\tau$ at the time of pregnancy recognition (Mann and Lamming, 2001), pulsatile secretion of $\mathrm{PGF}_{2 \alpha}$ would occur, leading eventually to luteolysis as a consequence of a lack of suppression in expression of oxytocin and estrogen receptors.

Furthermore, pregnancy-associated events such as regulation of localized immune function, angiogenesis, regulation of blood flow, and development of implantation sites require presence of PGHS-2 protein (Lim et al., 1997; Marions and Danielsson, 1999; Matsumoto et al., 2001, 2002). Reduced concentrations of IFN- $\tau$ have been shown to be inhibitory to $\mathrm{PGF}_{2 \alpha}$ secretion and PGHS-2 expression by endometrial cells in vitro (Parent et al., 2003; Thatcher et al., 2003). Therefore, underdeveloped embryos may not survive the process of implantation due to a negative effect of reduced IFN$\tau$ concentrations on PGHS-2, including induced degra- dation of PGHS-2 mRNA (Guzeloglu et al., 2004). However, these responses would contribute to extended interestrus intervals for cows losing embryos.

Effects of bST treatment on uterine OTR, $\mathrm{ER} \alpha$, and PR genes and ER $\alpha$ and PGHS-2 proteins of nonlactating Holstein cows were significant and diverse. However, the bST-reduced pregnancy rates in this study in nonlactating dairy cows may be due to overstimulation with bST. Critical regulatory components such as OTR, ER $\alpha$ mRNA, and ER $\alpha$ protein were stimulated, which might antagonize the pregnancy maintenance process in bSTtreated cows. Concentrations of OTR mRNA and ER $\alpha$ protein in endometrial tissues of bST-P cows were greater than in $\mathrm{P}$ cows, and were similar to $\mathrm{C}$ cows of the nontreated group. Therefore, bST-treated and inseminated cows that failed to conceive may have means for a luteolytic release of $\mathrm{PGF}_{2 \alpha}$, which could not be overcome by the conceptus. This would lead to early embryonic deaths and reduced fertility. The bSTtreated cows that did conceive had an appreciably greater conceptus size and length (Bilby et al., 2004), which may have contributed to their ability to sustain a pregnancy and reduce steady state concentrations of OTR mRNA, ER $\alpha$ mRNA, and ER $\alpha$ protein. Present results in nonlactating cows emphasize the importance of a comparable study in lactating cows to examine bST and pregnancy effects on endometrial gene expression, because cyclic lactating dairy cows have greater conception rates in response to bST at first service (Moreira et al., 2000, 2001; Santos et al., 2002).

\section{ACKNOWLEDGMENTS}

This study received financial support from the NRI Competitive Grant Program-USDA, grant no. 9835203-6367. This is Florida Agricultural Experimental Station Journal Series No.R-10312.

\section{REFERENCES}

Arosh, J. A., J. Parent, P. Chapdelaine, J. Sirois, and M. A. Fortier. 2002. Expression of cyclooxygenases 1 and 2 and prostaglandin $\mathrm{E}$ synthase in bovine endometrial tissue during the estrous cycle. Biol. Reprod. 67:161-169.

Badinga, L., A. Guzeloglu, and W. W. Thatcher. 2002. Bovine somatotropin attenuates phorbol ester-induced prostaglandin $\mathrm{F}_{2 \alpha}$ production in bovine endometrial cells. J. Dairy Sci. 85:537-543.

Bartol, F. F., R. M. Roberts, F. W. Bazer, G. S. Lewis, J. D. Godkin, and W. W. Thatcher. 1985. Characterization of proteins produced in vitro by periattachment bovine conceptuses. Biol. Reprod. 32:681-693.

Bathgate, R., W. Rust, M. Balvers, S. Hartung, S. Morley, and R. Ivell. 1995. Structure and expression of the bovine oxytocin receptor gene. DNA Cell Biol. 14:1037-1048.

Bezecny, I., J. Bartova, and J. Skarda. 1992. Growth hormone treatment increases oestrogen receptor concentration in the guineapig uterus. J. Endocrinol. 134:5-9.

Bilby, T. R., A. Guzeloglu, S. Kamimura, S. M. Pancarci, F. Michel, H. H. Head, and W. W. Thatcher. 2004. Pregnancy and bST in 
nonlactating dairy cows: I. Responses of the ovary, conceptus and IGF system. J. Dairy Sci. 87:3256-3267.

Boos, A. 1998. Immunohistochemical assessment of prostaglandin $\mathrm{H}-$ synthase in bovine endometrial biopsy samples collected throughout the estrous cycle. Anim. Reprod. Sci. 51:261-273.

Boos, A., J. Kohtes, A. Stelljes, H. Zerbe, and H. H. Thole. 2000. Immunohistochemical assessment of progesterone, oestrogen and glucocorticoid receptors in bovine placentomes during pregnancy, induced parturition, and after birth with or without retention of fetal membranes. J. Reprod. Fertil. 120:351-360.

Bradford, M. M. 1976. A rapid and sensitive method for the quantitation of microgram quantities of protein utilizing the principle of protein-dye binding. Anal. Biochem. 72:248-254.

Charpigny, G., P. Reinaud, J. P. Tamby, C. Creminon, and M. Guillomot. 1997a. Cyclooxygenase-2 unlike cyclooxygenase-1 is highly expressed in ovine embryos during the implantation period. Biol. Reprod. 57:1032-1040.

Charpigny, G., P. Reinaud, J. P. Tamby, C. Creminon, J. Martal, J. Maclouf, and M. Guillomot. 1997b. Expression of cyclooxygenase1 and -2 in ovine endometrium during the estrous cycle and early pregnancy. Endocrinology 138:2163-2171.

Danet-Desnoyers, G., C. Wetzels, and W. W. Thatcher. 1994. Natural and recombinant bovine interferons regulate basal and oxytocininduced secretion of $\mathrm{PGF}_{2 \alpha}$ and $\mathrm{PGE}_{2}$ by endometrial epithelial and stromal cells. Reprod. Fertil. Dev. 6:193-202.

DeJarnette, J. M., and C. E. Marshall. 2003. Effects of pre-synchronization using combinations PGF $(2 \alpha)$ and (or) GnRH on pregnancy rates of Ovsynch- and Cosynch-treated lactating Holstein cows. Anim. Reprod. Sci. 77:51-60.

Dubois, D. H., and F. W. Bazer. 1991. Effect of porcine conceptus secretory proteins on in vitro secretion of prostaglandin- $\mathrm{F}_{2 \alpha}$ and $\mathrm{E}_{2}$ from luminal and myometrial surfaces of endometrium from cyclic and pseudopregnant gilts. Prostaglandins 41:283-301.

Emond, V., L. A. MacLaren, S. Kimmins, J. A. Arosh, M. A. Fortier, and R. D. Lambert. 2004. Expression of cyclooxygenase-2 and granulocyte-macrophage colony-stimulating factor in the endometrial epithelium of the cow is up-regulated during early pregnancy and in response to intrauterine infusions of interferon- $\tau$. Biol. Reprod. 70:54-64.

Farin, C. E., K. Imakawa, T. R. Hansen, J. J. McDonell, C. N. Murphy, P. W. Farin, and R. M. Roberts. 1990. Expression of trophoblastic interferon genes in sheep and cattle. Biol. Reprod. 43:210-218.

Feldman, M., W. Ruan, I. Tappin, R. Wieczorek, and D. L. Kleinberg. 1999. The effect of $\mathrm{GH}$ on estrogen receptor expression in the rat mammary gland. J. Endocrinol. 163:515-522.

Fillion, F., N. Bouchard, A. K. Goff, J. G. Lussier, and J. Sirois. 2001. Molecular cloning and induction of bovine prostaglandin E synthase by gonadotropins in ovarian follicles prior to ovulation in vivo. J. Biol. Chem. 276:34323-34330.

Flint, A. P. F., H. J. Stewart, G. E. Lamming, and J. H. Payne. 1992. Role of the oxytocin receptor in the choice between cyclicity and gestation in ruminants. J. Reprod. Fertil. Suppl. 45:53-58.

Fuchs, A. R., O. Behrens, H. Helmer, C.-H. Liu, C. M. Barros, and M. J. Fields. 1990. Oxytocin and vasopressin receptors in bovine endometrium and myometrium during the estrous cycle and early pregnancy. Endocrinology 127:629-636.

Gross, T. S., W. W. Thatcher, P. J. Hansen, and S. D. Helmer. 1988. Presence of an intracellular endometrial inhibitor of prostaglandin synthesis during early pregnancy in the cow. Prostaglandins 35:359-378

Guzeloglu, A., P. Subramaniam, F. Michel, and W. W. Thatcher. 2004. Interferon- $\tau$ induces degradation of prostaglandin $\mathrm{H}$ synthase-2 mRNA in bovine endometrial cells through a transcription dependent mechanism. Biol. Reprod. 71:170-176.

Ing, N. H., T. E. Spencer, and F. W. Bazer. 1996. Estrogen enhances endometrial estrogen receptor gene expression by a posttranscriptional mechanism in the ovariectomized ewe. Biol. Reprod. 54:591-599.

Iwai, M., K. Yasuda, M. Fukuoka, T. Iwai, K. Takakura, S. Taii, S. Nakanishi, and T. Mori. 1991. Luteinizing hormone induces progesterone receptor gene expression in cultured porcine granulosa cells. Endocrinology 129:1621-1627.
Kim, S., Y. Choi, F. W. Bazer, and T. E. Spencer. 2003. Effects of the estrous cycle, pregnancy and interferon-tau on cyclooxygenase 2 (COX-2) expression in ovine endometrium. Reprod. Biol. Endocrinol. 1:58.

Kimmins, S., and L. A. MacLaren. 2001. Oestrous cycle and pregnancy effects on the distribution of oestrogen and progesterone receptors in bovine endometrium. Placenta 22:742-748.

Kirby, C. J., W. W. Thatcher, R. J. Collier, F. A. Simmen, and M. C. Lucy. 1996. Effects of growth hormone and pregnancy on expression of growth hormone receptor, insulin-like growth factor-1 and insulin-like growth factor binding protein-2 and -3 in bovine uterus, ovary, and oviduct. Biol. Reprod. 55:996-1002.

Klotz, D. M., S. C. Hewitt, P. Ciana, M. Raviscioni, J. K. Lindzey, J. Foley, A. Maggi, R. P. DiAugustine, and K. S. Korach. 2002. Requirement of estrogen receptor-alpha in insulin-like growth factor-1 (IGF-1)-induced uterine responses and in vivo evidence for IGF-1/estrogen receptor cross-talk. J. Biol. Chem. 277:8531-8537.

Lamming, G. E., and G. E. Mann. 1995. Control of endometrial oxytocin receptors and prostaglandin $\mathrm{F}_{2 \alpha}$ production in cows by progesterone and oestradiol. J. Reprod. Fertil. 103:69-73.

Lee, A. V., C. N. Weng, J. G. Jackson, and D. Yee. 1997. Activation of estrogen receptor-mediated gene transcription by IGF-I in human breast cancer cells. J. Endcorinol. 152:39-47.

Lewis, G. S., W. W. Thatcher, F. W. Bazer, and J. S. Curl. 1982. Metabolism of arachidonic acid in vitro by bovine blastocysts and endometrium. Biol. Reprod. 27:431-439.

Lim, H., B. C. Paria, S. K. Das, K. E. Dinchuk, R. Langenbach, J. M. Trzaskos, and S. K. Dey. 1997. Multiple female reproductive failure in cyclooxygenase 2-deficient mice. Cell 91:197-208.

Liu, J., M. Antaya, A. K. Goff, D. Boerboom, D. W. Silversides, J. G. Lussier, and J. Sirois. 2001. Molecular characterization of bovine prostaglandin G/H Synthase-2 and regulation on uterine stromal cells. Biol. Reprod. 64:983-991.

Lucy, M. C., W. W. Thatcher, R. J. Collier, F. A. Simmen, Y. Ko, J. D. Savio, and L. Badinga. 1995. Effects of somatotropin on the conceptus, uterus, and ovary during maternal recognition of pregnancy in cattle. Domest. Anim. Endocrinol. 12:73-82.

Mann, G. E., and G. E. Lamming. 1994. Use of repeated biopsies to monitor endometrial oxytocin receptors in the cow. Vet. Rec. 135:403-405.

Mann, G. E., and G. E. Lamming. 2001. Relationship between maternal endocrine environment, early embryo development and inhibition of the luteolytic mechanism in cows. Reproduction 121:175-180.

Mann, G. E., G. E. Lamming, R. S. Robinson, and D. C. Wathes. 1999. The regulation of interferon- $\tau$ and uterine hormone receptors during early pregnancy. J. Reprod. Fertil. 54:317-328.

Marions, L., and K. G. Danielsson. 1999. Expression of cyclooxygenase in human endometrium during the implantation period. Mol. Hum. Reprod. 5:961-965.

Matsumoto, H., W. Ma, T. Daikoku, X. Zhao, B. C. Paria, S. K. Das, J. M. Trzaskos, and S. K. Dey. 2002. Cyclooxygenase-2 differentially directs uterine angiogenesis during implantation in mice. J. Biol. Chem. 277:29260-29267.

Matsumoto, H., W. Ma, W. Smalley, J. Trzaskos, R. M. Breyer, and S. K. Dey. 2001. Diversification of cyclooxygenase-2-derived prostaglandins in ovulation and implantation. Biol. Reprod. 64:1557-1565.

McCracken, J. A., E. E. Custer, and J. C. Lamsa. 1999. Luteolysis: A neuroendocrine-mediated event. Physiol. Rev. 79:263-324.

Meikle, A., L. Sahlin, A. Ferraris, B. Masironi, J. E. Blanc, M. Rodriguez-Irazqui, M. Rodriguez-Pinon, H. Kindahl, and M. Forsberg. 2001. Endometrial mRNA expression of oestrogen receptor $\alpha$, progesterone receptor and insulin-like growth factor-I (IGF-I) throughout the bovine oestrous cycle. Anim. Reprod. Sci. 68:45-56.

Mishra, D. P., H. H. D. Meyer, and B. S. Prakash. 2003. Validation of a sensitive enzyme immunoassay for 13,14-dihydro-15-keto- 
$\mathrm{PGF}_{2 \alpha}$ in buffalo plasma and its application for reproductive health status monitoring. Anim. Reprod. Sci. 78:33-46.

Moreira, F., C. Orlandi, C. A. Risco, R. Mattos, F. Lopes, and W. W. Thatcher. 2001. Effects of presynchronization and bovine somatotropin on pregnancy rates to a timed artificial insemination protocol in lactating dairy cows. J. Dairy Sci. 84:1646-1659.

Moreira, F., C. A. Risco, M. F. A. Pires, J. D. Ambrose, M. Drost, and W. W. Thatcher. 2000. Use of bovine somatotropin in lactating dairy cows receiving timed artificial insemination. J. Dairy Sci. 83:1237-1247.

Newton, C. J., R. Buric, T. Trapp, S. Brockmeier, U. Pagotto, and G. K. Stalla. 1994. The unliganded estrogen receptor (ER) transduces growth factor signals. J. Steroid Biochem. Mol. Biol. 48:481-486.

Parent, J., C. Villeneuve, A. P. Alexenko, A. D. Ealy, and M. A. Fortier. 2003. Influence of different isoforms of recombinant trophoblast interferons on prostaglandin production in cultured bovine endometrial cells. Biol. Reprod. 68:1035-1043.

Payne, J. H., and G. E. Lamming. 1994. The direct influence of the embryo on uterine $\mathrm{PGF}_{2 \alpha}$ and $\mathrm{PGE}_{2}$ production in sheep. J. Reprod. Fertil. 101:737-741.

Robinson, R. S., G. E. Mann, G. E. Lamming, and D. C. Wathes. 1999. The effect of pregnancy on the expression of uterine oxytocin, oestrogen and progesterone receptors during early pregnancy in the cow. J. Endocrinol. 160:21-33.

Robinson, R. S., G. E. Mann, G. E. Lamming, and D. C. Wathes. 2001. Expression of oxytocin, oestrogen and progesterone receptors in uterine biopsy samples throughout the oestrous cycle and early pregnancy in cows. Reproduction 122:965-979.

Salamonsen, L. A., and J. K. Findlay. 1990. Immunocytochemical localization of prostaglandin synthase in the ovine uterus during the oestrous cycle and in early pregnancy. Reprod. Fertil. Dev. 2:311-319.

Santos, J. E. P., S. O. Juchem, R. L. A. Cerri, K. N. Galvão, R. C. Chebel, W. W. Thatcher, C. S. Dei, and C. R. Bilby. 2004. Effect of bST and reproductive management on reproductive performance of Holstein dairy cows. J. Dairy Sci. 87:868-881.

Spencer, T. E., and F. W. Bazer. 1995. Temporal and spatial alterations in uterine estrogen receptor and progesterone receptor gene expression during the estrous cycle and early pregnancy in the ewe. Biol. Reprod. 53:1527-1543.

Spencer, T. E., W. C. Becker, P. George, M. A. Mirando, T. F. Ogle, and F. W. Bazer. 1995. Ovine interferon- $\tau$ inhibits estrogen recep- tor up-regulation and estrogen-induced luteolysis in cyclic ewes. Endocrinology 136:4932-4944.

Spencer, T. E., A. Gray, G. A. Johnson, K. M. Taylor, A. Gertler, E. Gootwine, T. L. Ott, and F. W. Bazer. 1999. Effects of recombinant ovine interferon tau, placental lactogen, and growth hormone on the ovine uterus. Biol. Reprod. 61:1409-1418.

Thatcher, W. W. A. Guzeloglu, and F. Michel. 2003. Bovine endometrial (BEND) cells: Molecular and functional responses to phorbol ester and interferon-tau (IFN- $\tau$ ). Biol. Reprod. 68(Suppl 1):244. (Abstr.)

Thatcher, W. W., M. D. Meyer, and G. Danet-Desnoyers. 1995. Maternal recognition of pregnancy. J. Reprod. Fertil. Suppl. 49:15-28.

Thatcher, W. W., D. Wolfenson, J. S. Curl, L. E. Rico, J. J. Knickerbocker, F. W. Bazer, and M. Drost. 1984. Prostaglandins dynamics associated with development of the bovine conceptus. Anim. Reprod. Sci. 7:149-176.

Traish, A. M., and H. H. Wotiz. 1990. Monoclonal and polyclonal antibodies to human progesterone receptor peptide-(533-547) recognize a specific site in unactivated (8S) and activated (4S) progesterone receptor and distinguish between intact and proteolyzed receptors. Endocrinology 127:1167-1175.

Wang, H., B. Masironi, H. Erikkson, and L. Sahlin. 1999. A comparative study of estrogen receptors $\alpha$ and $\beta$ in the rat uterus. Biol. Reprod. 61:955-964.

Wathes, D. C., and G. E. Lamming. 1995. The oxytocin receptor, luteolysis and the maintenance of pregnancy. J. Reprod. Fertil. Suppl. 49:53-67.

Williams, W. F., G. S. Lewis, W. W. Thatcher, and C. S. Underwood 1983. Plasma 13,14-dihydro-15 keto $\mathrm{PGF}_{2 \alpha}(\mathrm{PGFM})$ in pregnant and nonpregnant heifers prior to and during surgery and following intrauterine injection of $\mathrm{PGF}_{2 \alpha}$. Prostaglandins 25:891-899.

Xiao, C. W., J. M. Liu, J. Sirois, and A. K. Goff. 1998. Regulation of cyclooxygenase and prostaglandin $\mathrm{F}$ synthase gene expression by steroid hormones and interferon-tau in bovine endometrial cells. Endocrinology 139:2293-2299.

Zarco, L., G. H. Stabenfeldt, S. Basu, G. E. Bradford, and H. Kindahl. 1988. Modification of prostaglandin $\mathrm{F}_{-2 \alpha}$ synthesis and release in the ewe during the initial establishment of pregnancy. J. Reprod. Fertil. 83:527-536.

Zheng, J., M. L. Johnson, D. A. Redmer, and L. P. Reynolds. 1996. Estrogen and progesterone receptors, cell proliferation, and c-fos expression in the ovine uterus during early pregnancy. Endocrinology 137:340-348. 